\title{
Market and Company Dimension in the Internet Age
}

\author{
Pierluigi Passaro \\ University of Bari Aldo Moro, Italy
}

doi: 10.19044/esj.2017.v13n25p12 URL:http://dx.doi.org/10.19044/esj.2017.v13n25p12

\begin{abstract}
The analysis and the study of market and company dimension takes on a particular interest for those who analyze and study the set of problems typical of company economy.

The starting point, nowadays, is the verification, from most experts openly shown, of the strict correlation of the two phenomena and, actually of their mutual influence. The analysis of these ones assumes a particular attention in light of what is happening in front of our eyes.

Those which appeared irrefutable certainties are now completely put into play again, very often, for determined aspects, completely overturned in regard to the previous certainties.

Our effort will consist in a detailed study of the two phenomena included in the great world of internet.

The company is a very complex organism. It consists of the organization in its inner of a set of functions, which have to be dimensioned one to the others to obtain a mutual functionality and a harmonic development. The organization of the company functions is a binding necessity for adherence of them to the needs and expectations of market to which the company turns its attention and interest.

This combination of functions with the chosen external environment represents the focal point of our interest. It is well clear that the changes which intervene either in one or in other environment, that must combine, necessarily produce some variations that assure the lingering of harmony already reached in the two sections.
\end{abstract}

Keywords: Market, new age, internet, brand nature

\section{Revisitation of concept of company dimension and of market nature and structure}

Through different interpretations of two important phenomena of company economy, it has to be underlined the phenomenon of new market nature, as fundamental target in a company life. 
The expanding of principles imposed by overflowing phenomenon of marketing in the company management, has determined the changed relationship between company and market. This has caused a significant supremacy of market over company. The organizzative and manageriale aspects of technical, commercial and financial nature have suffered a particular evolutive trend, strictly linked to market and its nature. But the market that today company has in front of itself, is changed in its nature and structure, therefore from this comes a complex serie of problems for the company which has to face absolutely new situations.

We refer to the internet world, virtual entity, and then with particular boundaries and potentialities.

The company is polifunctional organism and needs a harmonic coordination among the various operative functions.

It has already been said about the organization of such functions in the inner of company organism (the famous "productive combinations" as Renzi called them)

But such harmony can not be born exclusively in the inner of the company because it is necessary that it has a favorable acceptance from the external environment (market). Such acceptance is assured when the acknowledgement with market results positive (productive utilizations). But the company functions, of which we are talking about, prove to be instrumental for the definition of an optimal dimension. Therefore as a consequence the dimensions turns out to be in harmony with the exigences of market.

It will be said that today this reasoning results to be rather obsolete for the new adopted technologies which allow in a certain way the crossing of this expressed harmony.

The innovation allows definitively nowadays to the little to express itself on market as never has been possible once, either qualitatively or quantitatively.

But fundamentally the expressed principle exists today because substantially the modalities are always the same, they vary only in their exterior form.

All what expressed till now confirms the principle that the company dimensioni is a harmony with every company function and that, above all, it reaches an optimal result when market embraces with approval its expressions.

The concept of company dimension passes through an evolutive process which starts from an exclusively internal to company conception in relation with the technical characteristics of the developed activity. In this phase the prevailing trend, if favorable conditions are present, is the preference to the "great". Such an attribute allows to enlarge the possibilities 
of development and then more easily to reach prevalence conditions over market. But the great structure, sometimes enormous, shows extremely negative aspects referring to the rigidity and stickiness which it presents during the exercise of its functions.

These limits, barely outlined, have allowed a generalized preference to the "middle or little" with characteristics of flexibility and of easier adaptability to the growing variability on markets.

In these first evolutive phases of the concept of company dimensions, they organizzative and managerial characteristics of company appear prevalent, which tries to impose its own strategy and to adapt market to them.

Little by little the evolution of adopted techniques and above all the growing importance in marketing management and its analysis techniques of markets have determined a prevailing priority of market on the company structure and then on its dimension. The company has to adapt its multiple functions to the characteristics of market or of markets it wants to reach.

About the study of market, much has been deepened, but not everything is thorough when the present state of communication techniques or the new function of Internet is examined.

\section{What is market today}

Digitalization of market. Disappearance of boundaries of one market. The traditional market does not exist anymore. The whole world is a market. This modifies radically the approaches to it. Then the typologies of company structures are noticeably varied.

From this comes that the traditional concept of company dimension has no reason to exist.

The concepts of little, medium and great dimensions are today anachronistic expressions.

The consequence is that a little company can reach all boundaries of the earth, and one so-called great company is able to satisfy a little source of it.

From this derives that the exigence of company to start a process of internationalization fails, because it is not from this process that the company wins the competition.

The referring parameters are others and then others are the methodologies of managerial arrangement that company structures must implement.

Today it is no more the so-called market (better said, operative environment external to the company) to influence the so-called company dimension because it is no more possible to consider limitative fences either 
to company or to environment. Therefore speaking about company internationalization is a limitative concept and then wrong.

The concepts of company and market dimensions result today totally vanished, according to the traditional parameters.

Markets are not adaptable in local, regional, national, international, company dimensions are not adaptable in little, medium, and big.

This fact persuades us to review totally the organizations and actuations of all human activities (economical or not) in our days.

The execution of them is nonetheless intense and frenzied. It is then possible to define it an "organized disorder".

Why to talk about company and markets dimension?

Till now, in modern economy, the two concepts have influenced themselves. Market was standardized to the geographic boundaries in which the company activity spread out or to commodities boundaries. Dimension war noticeably influenced by geographical and commodities characteristics of market where company managed to show its presence. Today all this is no more acceptable.

The two concepts are no more reciprocally easily influenced one between the other, and they almost result indifferent.

Market is better definable as "external operative environment" of a company; the dimension of the same has no correspondence with external environment. We assist to a so-called little company which stands out in an enormous environment just as a s-called big company in an inferior external environment.

In this innovative situation of company and its functions, we must verify that repercussions on marketing show no decrease at all.

The company exigences typical of marketing remain untouched.

The knowledge of external environments is fundamental; thus also the adaptation of the operative choices, internal to company, to the external environment. The methodologies appear innovative and particularly refined.

In conclusioni we want to prove that the concept of traditional market does not exist anymore, and consequently the company dimensions which were strongly influenced turn to be a phenomenon, no more so important in the evolution of company life.

Once marketing tended to reach, in market analysis, the one to one target.

This appears today a real paradox. The external operative environment, as defined by us the traditional market, is an indistinct and generalized goal. The approach modalities to external environment are so sophisticated and technologically innovative, to prevent to potential buyers any possibility of alternative choice. 


\section{Development of the two concepts}

The possibility to achieve instantaneously any part of the Earth thanks to the advanced communication techniques, sets the company in the situation of being able to know in depth this reality and the respective characteristics.

We find ourselves in an absolutely new and undetermined sphere. That is, we go in the immense net of "internet"; it concerns a great virtual market, which presents for its specific characteristics, a set of very complex problems for the company, that belongs to the "real" world.

Market, in its traditional meaning, appears today obsolete. Internet rules, that is a virtual setting, not definable in its material and immaterial limits, exactly because virtual.

Company, in our opinion, appears uncertain and unlikely adaptable to something that exists and does not exist. Here the difficulties are born to approach to an entity of this kind, with significative difficulties of adapting their own skills in front of an entity which slips away to the attempts of measuring the capacities and wills of acceptance of proposals that start from the company world, strictly anchored to the concrete and easily measurable reality.

The effort for little and big companies is that of reducing the material and easily measurable entities, the great virtual audience.

The computer revolution and the internet exploitation could have no significant repercussions in concepts and now traditional knowledges, and for them influenced by the systematic appeal to marketing, by everyone utilized, and particularly incident on internal (dimensions) and external (markets) aspects of company realities.

The use of marketing has determined an overturning of traditional approaches of companies in relation to market.

Initially company developed its activity of internale organization (the optimal organization of productive combinations) and then it turned to objective market and its productive utilizations. With the entrance of marketing in the company reality, it happened the turn upside down of the equation with the prevalence of analysis of objective market and then the consequent determinations related to the layout of productive factors.

In short, brand collects a set of positive characteristics that inspire trust and entrustment on consumers.

It is a sort of shield of seriousness, reliability and interactivity under which are collected one or more products already in circulation or others not yet present.

All this makes brand a value easily assimilated to the virtual goods that circulate in internet market. 
Possibilities of brand to expand on different markets. Which factors (intangible linked to characteristics typical of brand itself or material connected to products or product strictly linked to brand) are more influent for the development of brand on markets?

\section{Some reflections about brand nature and its evolution}

Birth of Brand (intangible value) linked to a product (material value) or to more products. Characteristics (material or intangible) which contribute to form a brand.

First strictly connected to one or more products, then able to circulate alone on markets.

Analysis of typologies of brand's birth with the goal of verifying which of them lets easier the the development on more markets. Is brand an intangible or material good?

In this virtual scenery it becomes extremely difficult to choose the objective market of the company. The difficulties consist essentially in transferring the "virtual" in "real". Here insists the skill of company operators.

The circulation of a brand as a set of products and above all of values expressed by the company or by a group of companies, determines a highly positive effect, which appears then tangibly for the repercussions that can be observed in the objective market or in real markets, where concretely are measured the efficacy and validity of activities exercised by the singular company.

To browse in internet for a company, means to throw messages without being able concretely to know the effective expectations of the potential addressee of the messages themselves.

For one company, this means to operate in the dark undermining all the fundamental rules for the operatively of a company as economical subject. In other terms, the company is obliged to ignore the fundaments dictated by marketing in the phase of the objective market's choice.

In this new scenery either of company and its organization or of market, which we will concern later more diffusely, we wonder if marketing function still takes on its importance.

Even now marketing stands out among all company functions, because from one side it contributes to harmonize more and more the company functions, and from the other side it assumes a vital importance for the adaption and harmonization of the same with the chosen market, even if with the necessary terms when it meets a big market about which we will talk later on.

Which are the potential expectations that the virtual scenery shows and that can appear more attractive for the company that operates in reality. 
The skill to individuate such expectations and to transfer them in reality represents the ability of manager. Thus are formed those famous points of strength that a company shows in relation to others, and that allow it to perform those competitive advantages in relation to the other operators of market.

The combination between the Internet net and company shows itself extremely difficult. It regards to compare a virtual world with a real entity. The first is a world of potentialities and expectations, the second is a real world for excellence.

Certainly the choice of an adequate strategy to attack a virtual world is almost impossible, being the same extremely vague and indistinct. The only real possibility for the company is that of spreading its own brand with exclusively fact-finding goals.

The internet world is constituted by many real worlds, very different one from the other, therefore it is very difficult for the company to get them and attack them almost blindly.

The internet world, virtual for excellence, is made of many real worlds, made by very different multitudes of life conditions, habits and expectations. So different as it is not possible to attack them with a unique message.

The manager skill is just to identify those that can actually represent some objective markets, because more easily adaptable to the characteristics of productive combinations expressed by company.

At that point only that process can begin, that is the link between company and maket and above all between this last and the measure of either physical or economical dimension of company.

Market and dimension are reciprocally easily influenced factors; on the contrary, in light of the modern conception of marketing it is market to influence the measure of dimension. It is in fact prevailing in this viewpoint the market that determines the potentialities of company, because, in the construction of a development plan of company structure, market and its shape determine the potentialities of the offer.

The two factors must mutually know each other, on the contrary, the meeting is in the dark: in such operations one factor must necessarily know the other.

In the absence of such mutual knowledge it is not recommended to operate. A damage could be produced for both factors that meet. Besides to operate in the dark is never advisable in any circumstance.

Definitively there is always a relationship between company dimension and market.

Beyond the need of determined physical necessities of the systems, regarding the characteristics of production. 
It is important to point out that the company activity is instrumental to the chosen objective market, and not the contrary.

The company works with the goal of satisfying some needs. From this the necessity to privilege the study about needs to satisfy and then to proceed to the organization of the company.

This concept does not change if it deals with new products to put into market; in this case the modern techniques, that marketing suggests, aimed to the birth of determined needs to satisfy with new productions, supply to create the suitable market, whose potentialities at that point will condition the company activities.

Even in this maximum possibility, it is always market that expresses its final judgement, even if solicited in the creation of related needs.

From that moment on, it is always market that influences the company in the organization and arrangement or related products and services.

Nowadays we attend a real revolution in the communications field and above all in the use of an immense virtual platform - Internet.

To these events are not certainly irrelevant the companies that with their activities and organization use definitely such news, with the aim to exploit market at best.

Let us see in which way and up to where these news are used by companies. It is what we will try to develop in the follow-up of this work. Today the virtual world of internet floods every sector of civil life.

If to a certain extent, the phenomenon can be considered result of the progress, to many others it appears extremely damaging.

The excessive use of such instrument can cause a disjuncture between real and virtual; witnesses are the multiple debates that nowadays are developed about these arguments.

It is undeniable that using almost totally these instruments brings to the mental loss of coordinated of real life, with inevitable damaging consequences.

Romans used to say "est modus in rebus" and this expression appears more than ever relevant in the world of today.

Such are the considerations that invade the sphere of civil life, but it is likewise important that is noticed by supervisors of the economical world and the businesslike one in particular.

It appears evidently fundamental for the civil progress that the economical world always has helm directed to the reasonable and suitable use of these instruments.

"Virtual" is what exists in power but not in action.

Virtuality is potentiality of achieving in a determined action or of producing a determined effect. 
This the exact meaning of virtual or virtuality. What exists potentially but not effectively or really.

All this appears far enough from the real meaning of economical situations and happenings.

The efforts consists in transferring virtuality, that is those characteristics which exist potentially, in real situations and happenings, with the goal to be carefully evaluated but business economy.

It is very difficult, for the economist, to compare virtual to real.

Certainly the expectations, necessary to face expansion plans, are very important but they can not remain similar; it is necessary that probable becomes real. Only in this way it is natural to set up programmers and real plans.

It is fundamental that market is analyzed in its quantitative and qualitative consistence.

Ascertained that dimension, beyond possibilities and expectations related to its internal structure, of technical, technological nature, productive capacity, financial capacity, depends only on the objective market that is chooses, enormous and almost insurmountable obstacles rise, when such market is that till now examined, that is virtual, indefinite like Internet net.

After all Internet is a great virtual audience that embraces the whole terrestrial globe.

Therefore, everybody, conveniently equipped, can browse supporting a cost.

This web surfing is of course allowed even to companies.

But these last ones have different goals in surfing. They in fact address to this enormous scenario to fulfill the companies' own interests.

They realize nonetheless that the operation is highly difficult, if not impossible. The obstacles that companies have to face depend on the virtual character of the audience they go through. It results in fact difficult to adopt in such circumstances their own technologies to attack a determined market. The browsing nonetheless is not totally negative. The company has an opportunity to exploit: spread of company's brand, of its aspirations, of its fundamental values it supports.

In other terms, the opportunity we are talking about is the so-called "brand" that has to be diffused, first in indistinct and generalized way, but that later will allow very interesting restitutions, to use in the singular objective markets, this time real and aware.

In the internet world potentialities and expectations are the same and remain the same.

In the company world, potentialities are real and concern its own organization and the consequent expectations are real. 
The comparison between the two appear impossible and has a value only at the knowledge level one of the other.

The analysis has a double destination: market and identification of characteristics of this market (in-depth analysis of priority of needs to satisfy in generalized way).

Company needs to know in a complete and exhausted way its objective market: such necessity appears useless and difficult. In a likewise situationt it is clear the difficulty of building an efficient promotional campaign.

It appears like who, with bow and arrows, has a target to reach. At first sight such goal will seem out of reach.

This situation puts company in the double situation of not being able to identify in its coordinates its own market and consequently of meeting serious difficulties in building its promotional campaign.

In this serious situation company finds then itself when it starts, necessarily, to operate in a "virtual" market. The message then will have to be very generalized and destined to satisfy in a superficial way the categories of needs to fulfill.

In other terms, company will manage to get its potential clients, operating in that, now limited, sphere of buyers who love browse in the vast virtual market and will help them to choose what to buy.

This situation, while upsetting completely the elements of a classical and traditional exercise of marketing activities, obliges the company to reconsider the classical characteristics of marketing and then to limit building programmer aimed to well defined and easily identified market, and measurable to their capacities of incorporation and then with useful repercussions and compatible with the company potentialities.

This situation's consequence is glimpsed in the impossibility of a strict correlation between market and company.

The dimension of an economical structure is no more easily influenced by characteristics of its objective market, and then it will be affected exclusively by its own functional capacities and will work in function of these capacities. The market's virtuality will define such situation of operational generality.

This situation has clear repercussions either internal or external to company.

The internal consequences refer to the expansive capacity of the structure and then to major and better productive potentialities. The external repercussions influence considerably the possibility of building adequate communication plans.

Either the first or the second must necessarily challenge themselves with the present and future potentialities of absorption of addressees' 
markets. Similar characteristic appear vague and uncertain because unlikely measurable and predictable; it deals clearly with virtual skills.

Ultimately it is necessary that company builds its target in a certain way, well defined in its dimensions and potentialities, and then easily identifiable.

We return thus to the traditional situation and then to the possibility of a mutual influence between company and its dimension.

The binomial market-dimension must necessarily have the characters of identification well evident and measurable.

The correlation overturns itself, it is no more the singular consumer to stand out and influence considerably in the relation with company. A new configuration then happens about offer and demand.

Technology has reached not easily conceivable levels. So important to control everything and everybody.

In front of such scenario it comes spontaneous, to an even distracted observer, to study what happens and is happening, to try to reaffirm first place of the intellect over technology.

Ultimately everything is born from human mind, but the process is so quick that brain in a certain way remains overcome. Then it is necessary to turn on the wonderful and incomparable man's machine, that is brain.

It is then necessary to analyze, deepen and predict all what is in front of us, not to be ourselves in the end overcome.

Let us try ourselves not to be devoured by the instruments that mind has made available for us. put at our disposal.

\section{Conclusion}

In the end, every company must work in a new scenery. It will have to use for its goals what the new audience offers to it.

Definitively the company will have to adapt to the configuration and structure of market it chooses as its goal. This confirms what said more times: market influences the company structure, measure of its strategies, its dimension.

The communication system has suffered in the last years an evolutive process with significant dimensions. All this has affected all sectors of civil societies with repercussions in every activity branch with no exception.

This is a scenery that has determined innovative consequences, and very visible in the human activities.

In the end company is an organism always searching a perfect internal balance, not end in itself, but rather instrumental to the complete insertion in the exigences of external environment. 
The referring market imposes this balance, in order that the expectations are fully satisfied.

It is then clear that variations that occur in the external environment, nowadays more and more urgent, impose the same adaptation of company structures, and signally I refer to the reshaping of company functions.

Definitely "Internet" can be considered a great virtual audience, where companies activity can affect only exploiting the modern and quick communication system, and let a brand circulate.

After this probable cognitive operation, the company will move to the choice of one or more real objective markets and affect with its own programmers aimed to spread.

For all what considered now, we must close with the evident consideration that Internet is not surely that new market to which companies can turn their attention, and to which less than ever be able to decide which dimension is possible to imagine in front of a pseudo-market, that appears not at all useful to adopt the own organizzative, managerial, financial structures that one company needs to adopt.

All what expressed in the previous pages does not want to be a criticism to the examined events and to the phenomena in action of virtuality of studied sceneries.

We have faced subjects which are expression of the wider phenomenon that we can summary with "progress" in general.

So as the word itself expresses, progress represents something in favour of the general frame of civilization.

"Progress" then and not "regression": surely the involved interests are so many and so different as often they favor more some of them and less than others.

The important is that sectors which are involved by these new events and especially those who manage them, have the capacity and attitude to exploit skillfully such phenomena for their own advantage.

And we refer particularly to manager, that is the person who has responsibility of exploiting at best all these events so as to consider them a real progress for his own company and nothing else.

In conclusion in our opinion it is suitable to point out that the company system is still busy to fulfill its managerial targets, correlating itself to individual markets and coordinated in traditional marketing techniques.

All what we have previously explained represents then another possibility offered by modern technology, and so contributing to represent the modern objective market, by us identified and defined operative external environment; thus making it present and different from all what has preceded us in the concept of "virtual environment". 
Undoubtedly such instruments of transmission of informations and material products, highly innovative, allow all operators, either of little or great dimension, to approach to external environments, and to realize what today everywhere is defined "unique great virtual market".

The described analysis, even if summarily, does not tend to disadvantage reason, technology, because to them we owe the considerable accomplished progresses, and the best level in life conditions; in fact it helps us to reconsider the importance of soul and feelings, which, it seems, have been set aside.

The reflections born and expressed in the article are outcome of a careful exam of the scientific literature which has been produced about the argument in general, and particularly by the following authors: G.Golinelli, P. Kotler, M. Porter,E. Merlani, A. Renzi, N. Tridente, R. Varaldo.

\section{References:}

1. AA.VV., We've Got Blog, Perseus Publishing, Cambridge (Mass.) 2002.

2. Abruzzese, A. - Dal Lago, A., Dall'argilla alle reti. Introduzione alle scienze della comunicazione, Costa \& Nolan, Ancona-Milano 1999.

3. Antinucci, F., Computer per un figlio. Giocare, apprendere, creare, Laterza, Roma-Bari 2001.

4. Antinucci, F., La scuola si è rotta. Perché cambiano i modi di apprendere, Laterza, Roma-Bari 2001.

5. Bentivegna, S., La politica in rete, Meltemi, Milano 1999.

6. Bentivegna, S., Politica e nuove tecnologie della comunicazione, Laterza, Roma-Bari 20022.

7. Berners-Lee, T., L'architettura del nuovo Web, Feltrinelli, Milano 2001.

8. Berners-Lee, T. - Hendler, J. - Lassila, O., The Semantic Web, in «Scientific American», maggio 2001; <http://www.sciam.com/2001/0501issue/0501berners-lee.html >.

9. Bettetini, G. - Gasparini, B. - Cittadini, N., Gli spazi dell'ipertesto, Bompiani, Milano 1999.

10. Biolghini, D., Comunità in rete e Net Learning: innovazione dei sistemi organizzativi e processi di apprendimento nelle comunità virtuali, Etas, Milano 2001.

11. Blood, R., The Weblog Handbook, Perseus Books, Cambridge (Mass.) 2002.

12. Bonaiuto, M. (a cura di), Conversazioni virtuali. Come le nuove tecnologie cambiano il nostro modo di comunicare con gli altri, Guerini e Associati, Milano 2002. 
13. Boscarol, M., Ecologia dei siti Web, Hops Libri, Milano 2003.

14. Briggs, O. - Champeon, S. - Costello, E. - Patterson, M., Cascading Style Sheet (CSS): Fogli di stile per il web, Hoepli Informatica, Milano 2002.

15. Bruno, A., Comunità virtuali, Jackson libri, Bresso 2002.

16. Bruno, P., Le parole della rete, Mondadori, Milano 2001.

17. Bruno, P., Il cittadino digitale, Mondadori, Milano 2002.

18. Cagle, K., Professional XSL, Wrox Press Ltd., Birmingham 2001.

19. Carlini, F., Internet, Pinocchio e il Gendarme, Manifestolibri, Roma 1996.

20. Carlini, F. Lo stile del Web. Parole e immagini nella comunicazione di rete, Einaudi, Torino 1999.

21. Carlini, F., Divergenze digitali. Conflitti, soggetti e tecnologie della Terza Internet, Manifestolibri, Roma 2002.

22. Castells, M., La nascita della società in rete, Università Bocconi, Milano 2002.

23. Castells, M. - Viviani, S., Galassia Internet, Feltrinelli, Milano 2002.

24. Castro, E., HTML per il World Wide Web con XHTML e CSS, Pearson Education Italia, Milano 2003.

25. Ciotti, F., Manuale XML per le scienze umane, Laterza, Roma-Bari, in corso di stampa.

26. Ciotti, F. - Roncaglia, G., Il mondo digitale, Laterza, Roma-Bari 2000.

27. Colombo, F., Confucio nel computer, Nuova ERI-Rizzoli, Milano 1995.

28. Cremascoli, N. - Gualdoni, M., La lavagna elettronica. Guida all'insegnamento multimediale, Laterza, Roma-Bari 2000; in rete all'indirizzo http://www.laterza.it/laterza/librionline/cremascoli/cremascoli.htm.

29. Daconta, M.C. - Obrst, L.J. - Smith, K.T., The Semantic Web: a guide to the future of XML, Web services, and knowledge management, Wiley Pub., Indianapolis 2003.

30. Danesh, A. - Mehrassa, A. - Lau, F., Internet e sicurezza. Rendi sicuro il tuo computer e proteggi la tua privacy online, Jackson Libri, Milano 2002.

31. Davies, J., - Fensel, D. - Van Harmelen, F., Towards the semantic web: ontology-driven knowledge management, J. Wiley, ChichesterHoboken 2003.

32. De Biase, L., Il mago d'Ebiz. Libertà, velocità, comunità. Percorsi nella rivoluzione internettiana, Fazi, Roma 2000. 
33. De Biase, L., Edeologia. Critica del fondamentalismo digitale, Laterza, Roma-Bari 2003.

34. Di Corinto, A. - Tozzi, T., Hacktivism. La libertà nelle maglie della rete, Manifestolibri, Roma 2002.

35. Diodati, M. - Fornari, G., Internet per le pubbliche amministrazioni, Buffetti editore, Roma 2000.

36. Di Rocco, E. (“La Pizia”), Mondo Blog, Hops Libri, Milano 2003.

37. DuCharme, B., XML: the annotated specification, Prentice Hall, Upper Saddle River 1999.

38. Eletti, V. (a cura di), Che cos'è l'e-learning, Carocci, Roma 2002.

39. Fensel, D., Spinning the semantic Web: bringing the World Wide Web to its full potential, MIT Press, Cambridge (Mass.) 2003.

40. Ferri, P., La rivoluzione digitale. Comunità, individuo e testo nell'era di Internet, Mimesis, Milano 2001.

41. Ferri, P., Teoria e tecniche dei nuovi media. Pensare e lavorare nell'epoca della rivoluzione digitale, Guerini e Associati 2002.

42. Fierli, M., Tecnologie per l'educazione, Laterza, Roma Bari 2003.

43. Fiormonte, D. (a cura di), Informatica umanistica: dalla ricerca all'insegnamento. Atti del convegno "Computer, literature and philology”, Roma 1999-Alicante 2000, Bulzoni, Roma 2003.

44. Fleming, J., Web navigation. Il design delle interfacce web, Hops Libri, Milano 2000.

45. Floyd, M., Costruire siti Web con XML, Tecniche Nuove, Milano 2000.

46. Gambari, S. - Guerrini, M., Definire e catalogare le risorse elettroniche, Editrice Bibliografica, Milano 2002.

47. Ghislandi, P., Oltre il multimedia, Franco Angeli, Milano 1995.

48. Gigliozzi, G. - Ciotti, F., Introduzione all'uso del computer negli studi letterari, Bruno Mondadori, Milano 2003.

49. Goldfarb, C.F., The SGML Handbook, Oxford University Press, Oxford 1990.

50. Goldfarb, C.F. - Prescod, P., XML handbook, Prentice Hall, Upper Saddle River 2002.

51. Gomez-Perez, A. et al., Knowledge engineering and knowledge management: ontologies and the semantic Web. 13th international conference, EKAW 2002, Siquenza, Spain, October 1-4, 2002: proceedings, Springer, Berlin 2002.

52. Grimaldi, R., Le risorse culturali della rete, Franco Angeli, Milano 2003.

53. Guercio, M., Archivistica informatica. I documenti in ambiente digitale, Carocci, Roma 2002.

54. Gulbransen, D., XML schema, McGraw-Hill Italia, Milano 2002. 
55. Hafner, K., The Well: A Story of Love, Death and Real Life in the Seminal Online Community, Carroll \& Graf, New York 2001.

56. Hafner, K. - Lyon, M., La storia del futuro, Feltrinelli, Milano 1998 (ed. or. Where Wizard Stay Up Late, Simon \& Schuster, New York 1996).

57. Harel, D., Computer a responsabilità limitata: dove le macchine non riescono ad arrivare, Einaudi, Torino 2002.

58. Harold, E.R., XML: il linguaggio che rivoluzionerà il Web, Tecniche Nuove, Milano 2000.

59. Harold, E.R. - Means, W.S., XML. Guida di riferimento, Apogeo/O’Reilly, Milano 2001.

60. Himanen, P. et al., L'etica hacker e lo spirito dell'età dell'informazione, Feltrinelli, Milano 2001.

61. Hjelm, J., Creating the semantic Web with RDF: professional developer's guide, Wiley, New York 2001.

62. Holman, G.K., Definitive XSLT and XPath, Prentice Hall, Upper Saddle River 2002.

63. Horstmann, C.S., Concetti di informatica e fondamenti di Java 2, Apogeo, Milano 2000.

64. Horton, I., Java 2 SDK 1.4, Apogeo, Milano 2002.

65. Johnson, S., Interface culture. How new technology transforms the way we create and communicate, HarperEdge, San Francisco 1997.

66. Kay, M., XSLT: programmer's reference, Wrox Press Ltd., Birmingham 2001.

67. Krug, S., Don't make me think!, Hops Libri, Milano 2001.

68. Landow, G., L'ipertesto. Tecnologie digitali e critica letteraria, Bruno Mondadori, Milano 1998.

69. Laufer, R. - Scaletta, D., Texte, Hypertexte, Hypermedia, PUF, Paris 19952.

70. Livingston, D., CSS e DHTML, Tecniche Nuove, Milano 2002.

71. Longo, B., La nuova editoria. Mercato, strumenti e linguaggi del libro in Internet, Editrice Bibliografica, Roma 2001.

72. Lughi, G., Parole on line. Dall'ipertesto all'editoria multimediale, Guerini e Associati, Milano 2001.

73. Maiocchi, M. - Quintarelli, S., Internet per l'azienda, Edizioni Il Sole 24 Ore, Milano 2000.

74. Manera, G. - Metitieri, F., Dalla email al chat multimediale. Comunità e comunicazione personale in Internet, Franco Angeli, Milano 2000.

75. Maragliano, R., Nuovo manuale di didattica multimediale, Laterza, Roma-Bari 20027.

76. Mari, L., Accesso a database via Web, Apogeo, Milano 2001. 
77. Mari, L., Atomi \& bit: le ragioni del digitale e del multimediale, Guerini, Milano 2002.

78. Martinago, E. - Pasteris, V. - Romagnolo, S., Sesto potere. Guida per giornalisti, comunicatori aziendali, formatori nell'era di Internet, Apogeo, Milano 1997.

79. Masi, M., L'autore nella rete. Creatività e proprietà intellettuale nell'editoria multimediale, Guerini e Associati, Milano 2000.

80. Megginson, D., Structuring XML documents, Prentice Hall, Upper Saddle River 1998.

81. Metitieri, F., Comunicazione personale e collaborazione in rete. Vivere e lavorare tra email, chat, comunità e groupware, Franco Angeli, Milano 2003.

82. Metitieri, F. - Ridi, R., Biblioteche in rete. Istruzioni per l'uso, Laterza, Roma-Bari 2003 (nuova ed.); disponibile anche in rete all'indirizzo http://www.laterza.it/bibliotecheinrete/.

83. Minuti, R., Internet et le métier d'historien, PUF, Paris 2002.

84. Newcomer, E., Understanding Web services: XML, WSDL, SOAP, and UDDI, Addison Wesley, Boston 2002.

85. Nielsen, J., Web usability, Apogeo, Milano 2000.

86. Numerico, T. - Vespignani, A., Informatica per le scienze umanistiche, Il Mulino, Bologna 2003.

87. Otegem, M.V., XSLT: guida completa, Apogeo, Milano 2002.

88. Paccagnella, L., La comunicazione al computer, Il Mulino, Bologna 2000.

89. Pawson, D., Xsl-Fo, O’Reilly, Sebastopol 2002.

90. Pisanelli, D., Il medico in rete, Laterza, Roma-Bari 1999; in rete all'indirizzo http://www.laterza.it/laterza/librionline/pisanelli/pisanelli.asp.

91. Pozzi, P. - ENEA, Commercio elettronico e XML: scenari, tecnologie, applicazioni, Franco Angeli, Milano 2001.

92. Rheingold, H., Comunità virtuali, Sperling \& Kupfer, Milano 1994 (ed. or. The Virtual Community. Homesteading on the Electronic Frontier, Addison Wesley, Reading [Mass.] 1993; edizione riveduta The MIT Press, Cambridge [Mass.] 2000).

93. Rheingold, H., Smart Mobs. The Next Social Revolution, Perseus Publishing, Cambridge (Mass.) 2002.

94. Roncaglia, G., Libri elettronici - problemi e prospettive, in «Bollettino AIB», n. 4/2001, pp. 7-37.

95. Russo, P. - Sissa, G., Il Governo elettronico, Apogeo, Milano 2000.

96. Sala, V., E-book. Editoria elettronica, Apogeo, Milano 2001.

97. Sala M. - Vincenti M., Manuale del diritto di Internet, La Tribuna, Milano 2003. 
98. Salus, P., Casting the Net. From Arpanet to Internet and Beyond, Addison Wesley, Reading (Mass.) 1995.

99. Schmelzer, R., XML and web services unleashed, SAMS, Indianapolis 2002.

100. Sciuto, D., Introduzione ai sistemi informatici, McGraw-Hill Italia, Milano 2002.

101. Simone, R., La terza fase. Forme di sapere che stiamo perdendo, Laterza, Roma-Bari 2002.

102. Staglianò, R., Giornalismo 2.0. Fare informazione al tempo di Internet, Carocci, Milano 2002.

103. Stoll, C., Miracoli virtuali. Le false promesse di Internet e delle autostrade dell'informazione, Garzanti, Milano 1996.

104. Tidwell, D., Xslt, O’Reilly, Beijing 2001.

105. Thurow, S., Search Engine Visibility, New Riders, Indianapolis 2003.

106. Torvalds, L. - Diamond, D., Rivoluzionario per caso. Come ho creato Linux solo per divertirmi, Garzanti, Milano 2001.

107. Toschi, L., Il linguaggio dei nuovi media, Apogeo, Milano 2001.

108. Tosi, E. (a cura di), Il codice del diritto dell'informatica e di Internet. Normativa nazionale e comunitaria. La Tribuna, Milano 20034.

109. Trentin, G., Dalla formazione a distanza all'apprendimento in rete, Angeli, Milano 2003.

110. Turkle, S., La vita sullo schermo, trad. it., Apogeo, Milano 1996.

111. Usher, J. et al., New media and the humanities: research and applications. Proceedings of the first seminar: Computers, literature and philology, Edinburgh, 7-9 September 1998, Roma-Oxford 2002.

112. van Herwijnen, E., Practical SGML, Kluwer Academic Publishers, Boston-Dordrecht-London 1994.

113. Visciola, M., Usabilità dei siti web, Apogeo, Milano 2000.

114. Wallace, P., La psicologia di Internet, Raffaello Cortina, Milano 2000.

115. Weinberger, D., Arcipelago Web, Sperling \& Kupfer, Milano 2002.

116. Williams, S., Codice libero. Free as in Freedom: Richard Stallman e la crociata per il software libero, Apogeo, Milano 2003.

117. Williamson, H., La guida completa: XML, McGraw Hill Italia, Milano 2002.

118. Zhong, N. - Liu, J. - Yao, Y., Web intelligence, Springer, Berlin-New York 2003. 